\title{
Coastal dynamics and submarine permafrost in shallow water of the central Laptev Sea, East Siberia
}

\author{
Pier Paul Overduin ${ }^{1}$, Sebastian Wetterich ${ }^{1}$, Frank Günther ${ }^{1}$, Mikhail N. Grigoriev ${ }^{2}$, Guido Grosse ${ }^{1}$, \\ Lutz Schirrmeister $^{1}$, Hans-Wolfgang Hubberten ${ }^{1}$, and Aleksandr Makarov ${ }^{3}$ \\ ${ }^{1}$ Alfred Wegener Institute Helmholtz Center for Polar and Marine Research, Potsdam, Germany \\ ${ }^{2}$ Mel'nikov Permafrost Institute, SB RAS, Yakutsk, Russia \\ ${ }^{3}$ Arctic and Antarctic Research Institute, St. Petersburg, Russia \\ Correspondence to: Pier Paul Overduin (paul.overduin@awi.de)
}

Received: 13 May 2015 - Published in The Cryosphere Discuss.: 17 July 2015

Revised: 2 June 2016 - Accepted: 3 June 2016 - Published: 12 July 2016

\begin{abstract}
Coastal erosion and flooding transform terrestrial landscapes into marine environments. In the Arctic, these processes inundate terrestrial permafrost with seawater and create submarine permafrost. Permafrost begins to warm under marine conditions, which can destabilize the sea floor and may release greenhouse gases. We report on the transition of terrestrial to submarine permafrost at a site where the timing of inundation can be inferred from the rate of coastline retreat. On Muostakh Island in the central Laptev Sea, East Siberia, changes in annual coastline position have been measured for decades and vary highly spatially. We hypothesize that these rates are inversely related to the inclination of the upper surface of submarine ice-bonded permafrost (IBP) based on the consequent duration of inundation with increasing distance from the shoreline. We compared rapidly eroding and stable coastal sections of Muostakh Island and find permafrost-table inclinations, determined using direct current resistivity, of 1 and $5 \%$, respectively. Determinations of submarine IBP depth from a drilling transect in the early 1980s were compared to resistivity profiles from 2011. Based on borehole observations, the thickness of unfrozen sediment overlying the IBP increased from 0 to $14 \mathrm{~m}$ below sea level with increasing distance from the shoreline. The geoelectrical profiles showed thickening of the unfrozen sediment overlying ice-bonded permafrost over the 28 years since drilling took place. We use geoelectrical estimates of IBP depth to estimate permafrost degradation rates since inundation. Degradation rates decreased from over $0.4 \mathrm{~m} \mathrm{a}^{-1}$ following inundation to around $0.1 \mathrm{~m} \mathrm{a}^{-1}$ at the latest after 60 to 110 years and remained constant at this level as the du-
\end{abstract}

ration of inundation increased to 250 years. We suggest that long-term rates are lower than these values, as the depth to the IBP increases and thermal and porewater solute concentration gradients over depth decrease. For the study region, recent increases in coastal erosion rate and changes in benthic temperature and salinity regimes are expected to affect the depth to submarine permafrost, leading to coastal regions with shallower IBP.

\section{Introduction}

Submarine permafrost refers to solid earth material below modern sea level that has perennial temperatures below $0^{\circ} \mathrm{C}$. It contains and traps significant amounts of methane and organic carbon, which may be released to the atmosphere during permafrost warming and thawing (McGuire et al., 2009), if it is not oxidized before it reaches the seabed (Overduin et al., 2015). Cold sediment temperatures stabilized by shelf permafrost extend the gas hydrate stability zone (Dallimore and Collett, 1995) and the frozen sediment may limit gas diffusion into the water column and atmosphere (Shakhova and Semiletov, 2007). Despite its importance, little of what we know about submarine permafrost distribution and temperature is based on direct observation, especially on the East Siberian shelves, which make up over $80 \%$ of the potentially permafrost-affected arctic shelf area (Brown et al., 2001).

Most submarine permafrost originally formed as terrestrial permafrost on arctic shelves, exposed during Late Pleistocene cold periods, which was subsequently inundated by 
rising sea levels following the last glacial period. Even today, rapid coastal retreat along the ice-rich coastline of the Laptev and East Siberian shelf seas causes about $10 \mathrm{~km}^{2}$ of land loss annually (Grigoriev, 2008). Deglaciation after the Last Glacial Maximum led to sea-level rise in the Laptev Sea region more than 10 times as rapid as modern rates (Bauch et al., 2001), inundating most of the more than 1.5 million $\mathrm{km}^{2}$ East Siberian shelf region within several thousand years. Both processes (coastal erosion and sea-level rise) covered cold (less than $-2{ }^{\circ} \mathrm{C}$ at the seasonal damping depth) and thick (hundreds of metres) permafrost with seawater and seasonal sea ice, separating it from the cold air with mean annual temperatures of less than $-10^{\circ} \mathrm{C}$. In the coastal zone (shallower than $10 \mathrm{~m}$ ) of the Laptev Sea, bottom temperatures currently range from $1.6^{\circ} \mathrm{C}$ in summer to $-1.4^{\circ} \mathrm{C}$ in winter (Dmitrenko et al., 2011). After inundation, submarine permafrost began to equilibrate thermally with benthic temperatures. This temperature increase resulted in warming and thawing of permafrost below the seabed (Lachenbruch, 1957). Thawing also occurred due to penetration of saltwater into the seabed, which lowered the freezing point of the sediment's porewater. Thus, modern submarine permafrost can have temperatures below $0{ }^{\circ} \mathrm{C}$ but can contain little or no ice. What is generally observed, by geophysical methods or direct observations, in sediment cores, is the depth of ice-bonded permafrost (IBP) below the sea floor (which is equivalent to the thickness of the overlying unfrozen sediment). Direct current resistivity and controlled source electromagnetic techniques for the investigation of submarine permafrost have been established in a number of studies (Barnes, 1963; Constable, 2010; Corwin, 1983; Sellmann et al., 1989). Laboratory measurements of the bulk electrical properties of frozen porous media show the effect of ice content and thus saline porewater on electrical resistivity (Overduin et al., 2012). Sediment bulk electrical resistivity increases by orders of magnitude between icebonded, freshwater sediment and ice-free, saline sediment (Scott et al., 1990), making it suitable for the detection of the ice-bonded permafrost table.

Benthic temperature and salinity control warming of the sea floor and the rate of salt penetration into the sediment column, but there are a number of processes active in shallow water near the coastline that additionally affect permafrost following inundation. Sedimentation of eroded material, sediment resuspension and transport by wave action and by currents and the entrainment of suspended material and sediment in sea ice are important in determining initial rates of degradation in water depths where wave cycles and ice gouging can mix and erode the sea bed. Where the water depth is less than the maximum sea-ice thickness, bottomfast ice (BFI) forms (Solomon et al., 2008). Sea ice has a higher thermal conductivity than seawater, and BFI thermally couples the sea floor to the cold winter air temperatures, which can lead to seasonal freezing of the sediment and the injection of brines into the sediment (Harrison, 1982). Since

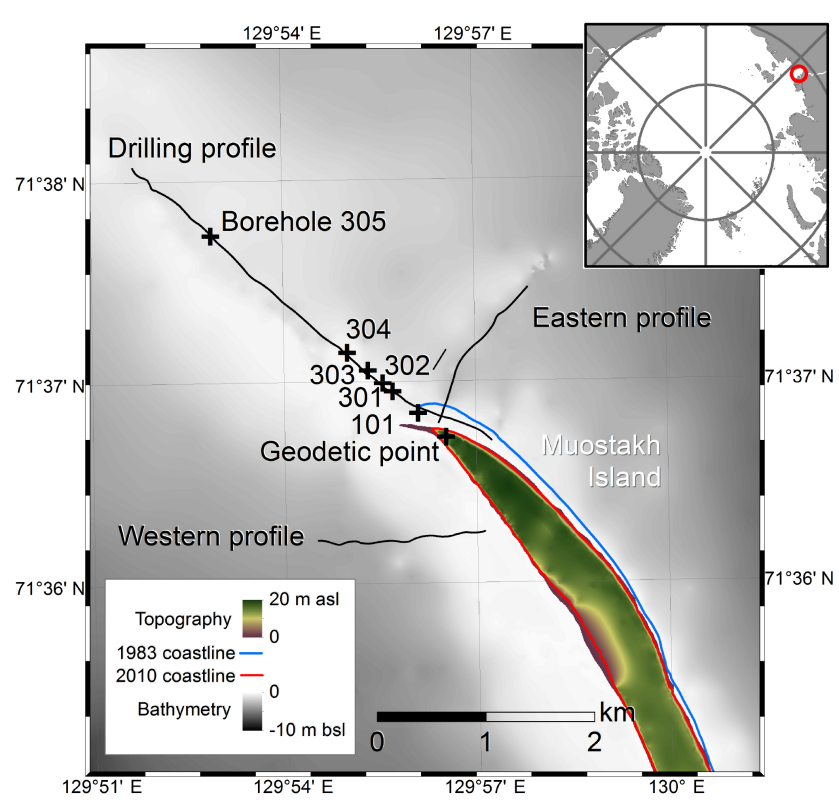

Figure 1. (a) The location of the study site in the central Laptev Sea, East Siberia, Russia. (b) The topography of Muostakh Island and the surrounding bathymetry. The reference geodetic point and borehole locations are shown by diamonds and the three geoelectric profiles by black lines. The blue line surrounding the island indicates the position of the coastline in 1983, the red line the coastline in 2010 .

the rate of coastal erosion affects sediment flux, and therefore bathymetry, submarine permafrost degradation rates following inundation are related to coastal erosion.

Our objective is to use inundation periods inferred from remote sensing, geophysical surveys and borehole observations of IBP to investigate the relationship between coastal erosion and submarine permafrost degradation beneath the shoreface.

\section{Study area}

Muostakh Island $\left(71.58^{\circ} \mathrm{N}, 130.01^{\circ} \mathrm{E}\right)$, a sliver of land about $40 \mathrm{~km}$ offshore Tiksi in the central Laptev Sea (Fig. 1), is an ideal site for the study of submarine permafrost processes (Are, 2003). About $10 \mathrm{~km}$ long and less than $500 \mathrm{~m}$ wide, the island is located $25 \mathrm{~km}$ north-east of the mainland and $15 \mathrm{~km}$ south-east of Bykovsky Peninsula. Ships leaving Tiksi, one of the major ports on the Northeast Passage, travel within sight of Muostakh Island, and it has therefore long been an object of research, from as early as the late nineteenth century. This research includes studies of coastal dynamics, and coastline erosion rates observed at Muostakh Island in the central Laptev Sea include some of the highest observed in the Arctic (Grigoriev et al., 2009). The island was originally the south-eastern continuation of the Bykovsky Peninsula coast and consists mainly of Late Pleistocene Ice Com- 


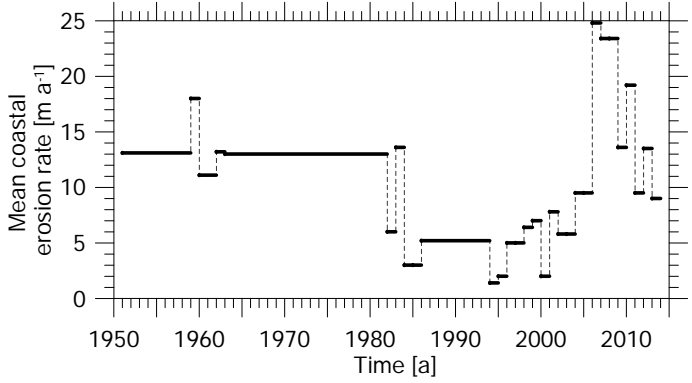

Figure 2. The mean annual erosion rate at the northern cape of $\mathrm{Mu}$ ostakh Island has been measured by determination of the position of the upper edge of the bluff relative to a geodetic point (measurements are indicated as mean values over a period) since 1951. The greater the absolute value, the higher the erosion rate (reproduced from Grigoriev et al. (2009) for data up to 2008).

plex (IC) deposits. IC deposits are ice-rich (Muostakh Island is composed of $87 \%$ ground ice by volume; Günther et al., 2015), polygenetic in origin and characterized at the ground surface by the polygonal network of ice wedges formed over thousands of years by meltwater infiltration into cold winter thermal contraction cracks (Schirrmeister et al., 2011b). Coastal thermo-erosion on Muostakh Island varies widely in intensity (from close to 0 to over $25 \mathrm{~m} \mathrm{a}^{-1}$ ) over a relatively small region (Grigoriev et al., 2009; Günther et al., 2015). The spatial variability of coastal retreat rates along the island's coastline offers an opportunity to investigate its influence on submarine permafrost development while other aspects of environmental forcing are similar.

IC coastlines are prevalent throughout much of the Laptev and East Siberian seas. On Muostakh Island, IC deposits are exposed along the east coast from below sea level up to the island's surface. Much of the Chukchi and Beaufort seas' coastlines are similarly ice-rich and can be expected to be subject to the same mechanisms of geomorphologic change in response to shifts in environmental drivers of coastal dynamics (Ping et al., 2011). Regionally, relevant shifts in the energy and water balances at the land-atmosphere interface (Boike et al., 2013), increases in Lena River discharge (Fedorova et al., 2015) and increases in the duration of open water and coastal erosion (Günther et al., 2015) have recently been observed, matching similar circumpolar observations (Barnhart et al., 2014).

\section{Materials and methods}

\subsection{Geodetic measurements of coastline position}

Coastal change rates on Muostakh Island have been estimated since the early 1950 s by combining on-site and remote sensing methods (Fig. 2; Grigoriev et al., 2009). A geodetic benchmark was established near the northern end of the island in 1950. Measurements were made at irregu- lar intervals thereafter, by measuring the distance from the geodetic benchmark to the top of the coastal bluff along various bearings, either with measuring tape or a theodolite. The coastline positions reported here were measured as the position of the upper edge of the coastal bluff along a bearing from the geodetic benchmark and the signal tower on Cape Muostakh, at the southern end of the Bykovsky Peninsula. Since there were unrecorded differences from year to year in how measurements were carried out, it is difficult to assess uncertainty in the measurements. Sources of uncertainty include determination of the direction in which coastal position was measured, small differences in time of year for measurements and difficulty in safely reaching the cliff edge. We conservatively estimate the measurements to be better than $\pm 0.5 \mathrm{~m}$. Between measurements in 2010 and 2011, the geodetic reference point was toppled by coastal erosion. For purposes of continuity, a network of survey points was established by theodolite in 2011 immediately thereafter to make a continuation of the measurement series possible. Ground control points were established to align field observations with remote sensing data (Günther et al., 2013).

\subsection{Temperature and electrical resistivity}

Benthic temperature and electrical conductivity were recorded using a bottom-moored conductivity $\left( \pm 0.1 \mathrm{mS} \mathrm{cm}^{-1}\right)$, temperature $\left( \pm 0.2^{\circ} \mathrm{C}\right)$ and water depth $( \pm 0.2 \%)(\mathrm{CTD})$ data logger. The CTD data logger (Minilogger, UIT Umwelttechnik $\mathrm{GmbH}$ ) was mounted on a metal plate and deployed with two $50 \mathrm{~m}$ cables attached to anchors. By dredging with a cat's claw anchor after deployment, the cables could be snagged and the data logger recovered. The data logger was deployed at $71.672^{\circ} \mathrm{N}, 129.996^{\circ} \mathrm{E}$ in $7.2 \mathrm{~m}$ water depth on 10 August 2008, just outside of the northeastern corner of the frame for Fig. 2. Data were collected hourly between 1 September 2008 and 31 August 2009. Although electrical conductivity values were measured and recorded, the inverse value (electrical resistivity) is reported here for comparison to the results of the geoelectrical surveys.

\subsection{Core and borehole data}

Sediments of onshore and offshore permafrost north of Muostakh Island were drilled during the Northern Expedition of the Siberian Branch of the Soviet Academy of Sciences (SBSAS) Melnikov Permafrost Institute Yakutsk in 1982 and 1983. Six boreholes were sunk up to $54 \mathrm{~m}$ depth and $2.5 \mathrm{~km}$ off the shore (in 1983) along a straight line across the shallow water zone between Cape Muostakh at the southern end of the Bykovsky Peninsula and the northern cape of Muostakh Island (Kunitsky, 1989; Slagoda, 2004). The boreholes were drilled using a portable rotary drill rig and a dry drilling technique. Metal casing was drilled through the sea ice water column and into the sediment to prevent water from 
entering the borehole. Temperature and geochemical data are summarized by Kunitsky (1989), while granulometric, cryolithologic and mineralogic data are presented by Slagoda (1993, 2004). Results from these publications, originally in Russian, are made available here to a non-Russian readership. Observations made during drilling from the land-fast ice in spring and during laboratory investigation of the cores included sediment temperature and lithology and porewater salinity. Borehole temperatures were measured in 1982 and 1983 using a thermistor string and a voltmeter. Sediment porewater from cores was analysed for total dissolved solids, which was converted to electrical resistivity based on the resistivity of a sodium chloride solution:

$R=0.55 \cdot$ TDS -0.97,

where $R$ is the electrical resistivity in $\Omega \mathrm{m}$ and TDS denotes the total dissolved solids in grams per $100 \mathrm{~g}$ solution. Locations of boreholes, their depths, water depth and the depth of the unfrozen/frozen interface beneath sea level are summarized in Table 1.

\subsection{Electrical resistivity and time of inundation}

Geoelectric surveys of submarine apparent resistivity collected on 21-24 August 2011 were combined with bathymetry measurements to invert for sub-bottom sediment resistivity, which gives an indication of the depths of saline sediment and of the underlying ice-bonded submarine permafrost. The results from three surveys are presented here, two profiles of $1.5 \mathrm{~km}$ length from the eastern and western coasts of the northern cape of Muostakh Island, as well as a profile of $4 \mathrm{~km}$ length along the historical borehole profile (Fig. 1). The sub-bottom apparent electrical resistivity profiles were collected using an IRIS Syscal Pro ${ }^{\mathrm{TM}}$ Deep Marine system. Voltages were measured around an electrical current injection dipole of $10 \mathrm{~m}$ size, using a floating electrode streamer towed behind a small boat. The injection and potential electrodes were stainless steel plates $(10 \times 30 \mathrm{~cm})$. Electrical potential was measured across 10 channels spanning between 20 and $110 \mathrm{~m}$. Electrode position (relative to a GPS aboard the boat), the injection current, measured electrode pair potentials and water depth (using an echo sounder with better than $\pm 0.1 \mathrm{~m}$ resolution attached to the boat) were recorded at intervals of at least $2 \mathrm{~m}$ as the array was towed. We used RES2DINV ${ }^{\mathrm{TM}}$ software to invert the apparent resistivity data via least-squares inversion for floating electrodes with a modelled water-layer resistivity, allowing for a sharp change in modelled resistivity across sediment surface. Model resistivity was smoothed to produce reasonable variations in the resistivity values. Prior to inversions, data values were inspected graphically and less than $0.1 \%$ of collected apparent resistivities were identified as outliers and removed. Inversions required fewer than five iterations in order to reach better than $5 \%$ root mean square error between modelled and observed resistivity. Relating estimated sediment resistivity
Table 1. Borehole characteristics.

\begin{tabular}{lllll}
\hline $\begin{array}{l}\text { Borehole } \\
\text { number }\end{array}$ & Latitude, longitude & $\begin{array}{l}\text { Water } \\
\text { depth } \\
(\mathrm{m})\end{array}$ & $\begin{array}{l}\text { Borehole } \\
\text { depth } \\
(\mathrm{m} \text { b.s.l. })\end{array}$ & $\begin{array}{l}\mathrm{IBP}^{\mathrm{b}} \\
\text { table } \\
\text { depth } \\
(\mathrm{m} \text { b.s.l. })\end{array}$ \\
\hline $101 \_82$ & $71.6162^{\circ} \mathrm{N}, 129.926^{\circ} \mathrm{E}$ & 0 & 52 & 0 \\
$301 \_83$ & $71.6183^{\circ} \mathrm{N}, 129.9208^{\circ} \mathrm{E}$ & 2.4 & 7.8 & 3.3 \\
$302 \_83$ & $71.6188^{\circ} \mathrm{N}, 129.9190^{\circ} \mathrm{E}$ & 3 & 10 & 4 \\
$303 \_83$ & $71.6199^{\circ} \mathrm{N}, 129.9156^{\circ} \mathrm{E}$ & 2 & 12 & 7 \\
$304 \_83$ & $71.6217^{\circ} \mathrm{N}, 129.9083^{\circ} \mathrm{E}$ & 3.4 & 50.7 & 8.3 \\
$305 \_83$ & $71.6254^{\circ} \mathrm{N}, 129.8958^{\circ} \mathrm{E}$ & 3 & 54 & 16 \\
\hline
\end{tabular}

${ }^{a}$ Data from Kunitsky (1989) and Slagoda $(1993,2004) .{ }^{b}$ IBP: ice-bonded permafrost.

to ice content requires either measurements on sampled sediment or some rather arbitrary assumptions. No resistivities were measured on samples from this site, since no recent drilling took place. Some literature values for sediment resistivity as a function of temperature, salinity and ice content exist. Kang and Lee (2015), for example, show an increase in electric resistivity on freezing for silt-sand mixtures with $40 \%$ saturation from around $100 \Omega \mathrm{m}$ to over $300 \mathrm{k} \Omega \mathrm{m}$. For $100 \%$ saturated mixtures with saline porewater, the resistivities can be expected to be around 4 to 10 times lower (Kang and Lee, 2015). Laboratory measurements of saline silty and sandy sediment, similar in grain size distribution to those at Muostakh Island, show that ice is present in the sediment for bulk resistivities over $10 \Omega \mathrm{m}$ (Overduin et al., 2012), although the boundary between ice-free and ice-bonded sediment may not be sharply defined, so that resistivity changes gradually with depth. We consider that any sand-silt mixture that is ice-bonded with fresh porewater, as is the case here based on the porewater concentrations from the drilling samples, and consistent with previous observations of submarine permafrost in the Laptev Sea, will have a resistivity not lower than $10 \Omega \mathrm{m}$, and probably higher than $100 \Omega \mathrm{m}$. This assumption is also based on laboratory measurements of bulk resistivity as a function of temperature and salinity for marine sediments which show that the change in bulk sediment resistivity from an unfrozen seawater-saturated sediment to a frozen ice-saturated sediment corresponds to a jump in resistivity from less than 10 to over $100 \Omega \mathrm{m}$ (Frolov, 1998; King et al., 1988; Overduin et al., 2012). Uncertainties in IBP depth estimated from resistivity profiles thus correspond to the depth range of the bulk sediment resistivity increase from 10 to $100 \Omega \mathrm{m}$.

Mean submarine permafrost degradation rate was calculated as the quotient of the depth to IBP $\left(z_{\mathrm{pf}}\right)$ and the time of erosion ( $t_{0}$; time of inundation). $z_{\mathrm{pf}}$ was either observed in sediment recovered from the boreholes, or was inferred from geoelectric inversions using the depth of the 10 and $100 \Omega \mathrm{m}$ isopleths. The time since inundation was determined using coastlines digitized from remotely sensed imagery. In addition to the remote sensing dataset used by Günther et al. (2015), we increased temporal resolution by adding coastal 
erosion observations based on a CORONA KH-4B satellite image dating from 24 July 1969, a HEXAGON image from 17 July 1975 and a SPOT-4 image taken on 1 July 2001. After stitching image tiles of the CORONA and HEXAGON images and pansharpening of the SPOT scene, each image was orthorectified to mean sea level using specific sensor models. In contrast to on-site measurements of the upper coastal bluff edge, we digitized the cliff bottom line as the location where inundation occurs in the form of thermoabrasion (Are, 1988). For consistency with the 1983 drilling campaign, as an important baseline, the coastline of 1983 was reconstructed based on an interpolation between digitized coastlines from high-resolution aerial and satellite images (1951, 1964, 1969, 1975, 2001, 2010 and 2011). Taking digitized coastlines as isolines of equal time, we estimated the time of inundation $\left(t_{0}\right)$ at the location of each sounding in 2011. Given a mean coastal erosion rate of $1.8 \mathrm{~m} \mathrm{a}^{-1}$ on Muostakh (Günther et al., 2015), interpolation was done to a raster size of $2 \mathrm{~m}$, corresponding to a resolution of at least 1 year. However, our geoelectric transects are concentrated around the northern cape, where more rapid erosion takes place, resulting in an almost monthly resolution. For two of the transects, some of the geoelectric measurement sites lay within the region flooded by seawater since 1951 (83 soundings from the borehole profile and 337 from the eastern transects). We calculated the period of inundation $\left(t_{\mathrm{sub}}\right)$ at the location of each sounding as

$t_{\mathrm{sub}}=t_{\mathrm{obs}}-t_{0}$,

where $t_{\mathrm{obs}}$ is the time of observation (2011) and $t_{0}$ the time of inundation raster cell value. This yields a mean rate of submarine permafrost degradation for this period of

$r_{\mathrm{deg}}=\frac{z_{\mathrm{pf}}}{t_{\mathrm{sub}}}$

Uncertainties in degradation rates derive from uncertainties in $t_{\text {sub }}$ and $z_{\text {pf }}$. The former are better than 1 year, based on the resolution of the shoreline rasterization. For the set of permafrost observations within the region for which remote sensing data exist, the positions of $z_{\mathrm{pf}}$ estimates for degradation rates are not based on extrapolation of coastal erosion rates from the current coastline, but on interpolation of coastline position between observations. Variations of coastal erosion rate on shorter timescales (the longest averaging period was 26 years between 1975 and 2001) may have occurred as observed by Lantuit et al. (2011) on the Bykovsky Peninsula but cannot be quantified for Muostakh. Uncertainty in period of inundation and degradation rate was calculated by assuming double the mean long-term erosion rate for the period prior to 1951 for each borehole position. Uncertainty in $z_{\mathrm{pf}}$ for borehole determinations was set at $0.5 \mathrm{~m}$ to allow for tidal variations $(<0.3 \mathrm{~m})$, sea level rise and uncertainty in determining core sediment depth in the borehole (estimated at better than $0.1 \mathrm{~m}$ ). The uncertainty in $z_{\mathrm{pf}}$ derived from resistivity profiles corresponds to the uncertainty of the depth of investigation of the geoelectric method. We have chosen a range of resistivities to cover the transition from unfrozen to frozen sediment (10 to $100 \Omega \mathrm{m}$ ), so that the range of depths associated with this transition corresponds to the uncertainty in the determination of $z_{\mathrm{pf}}$. Nautical charts of the early 1980s showing points of bathymetry measurements every $500 \mathrm{~m}$ and isobaths with an equidistance of $2 \mathrm{~m}$ were digitized and interpolated for the coastal waters around Muostakh Island, in order to account for shoreface profile changes.

\section{Results}

\subsection{Shoreface morphology}

Figure 1 shows coastlines of Muostakh Island from two different points in time. Based on data from Grigoriev et al. (2009), the mean erosion rates for the northern cape of Muostakh Island for the period of record (1951-2014) was $10.7 \mathrm{~m} \mathrm{a}^{-1}$ with variations between 2 and $25 \mathrm{~m} \mathrm{a}^{-1}$ (Fig. 2). This value includes multiple-year periods for which erosion rate was determined using remote sensing data. Observations between 1995 and 2014 were conducted in the field and give a mean erosion rate of $10.2 \mathrm{~m} \mathrm{a}^{-1}$. Longer term coastal erosion rates of over $10 \mathrm{ma}^{-1}$ decreased to less than $5 \mathrm{ma}^{-1}$ in 1984 and then fluctuated between 2 and $10 \mathrm{ma}^{-1}$ until 2006. In 2006/2007, rates at the northern cape increased to $25 \mathrm{~m} \mathrm{a}^{-1}$. The three periods with the most rapid rates have been observed in the past 9 years (2006-2007, 2007-2009, 2010-2011). Rates of coastal retreat along the eastern shore of the island reported by Günther et al. (2015) confirm recent higher rates of erosion relative to the long-term means. In that context, the rates shown here are more indicative of the increased rates of land loss at the exposed cape than of changes in erosion rates for the island as a whole. For example, the western coast of Muostakh Island has had mean coastal erosion rates of less than $1 \mathrm{~m} \mathrm{a}^{-1}$ (Fig. 1) for the past 60 years. The mean annual rates of erosion where the digitized coastlines intersected with the geoelectric profiles on the western and north-eastern sides of the island over the period 1982-2011 were 0.5 and $6.5 \mathrm{~m} \mathrm{a}^{-1}$, respectively, resulting in the inundation of $14 \mathrm{~m}$ (western shore) and over $180 \mathrm{~m}$ (eastern shore) of land over this period.

Based on positions reported in the field notes of the drilling campaigns (Kunitsky, 1989) core positions were charted and used to define the position of the north-western geoelectrical resistivity profile (Drilling profile in Fig. 1). Due to coastline retreat, the southern $1.4 \mathrm{~km}$ of this resistivity profile corresponded to what had been land at the time of coring in 1983, $645 \mathrm{~m}$ of which was within the drilling profile (Fig. 1). The altitude of the coastal bluff in 1983 exceeded 20 m a.s.l. (Fig. 3). Bathymetric profiling was used to survey modern water depths, and comparisons showed that shoreward of $2 \mathrm{~km}$ in the historical data (Fig. 3), coastal re- 

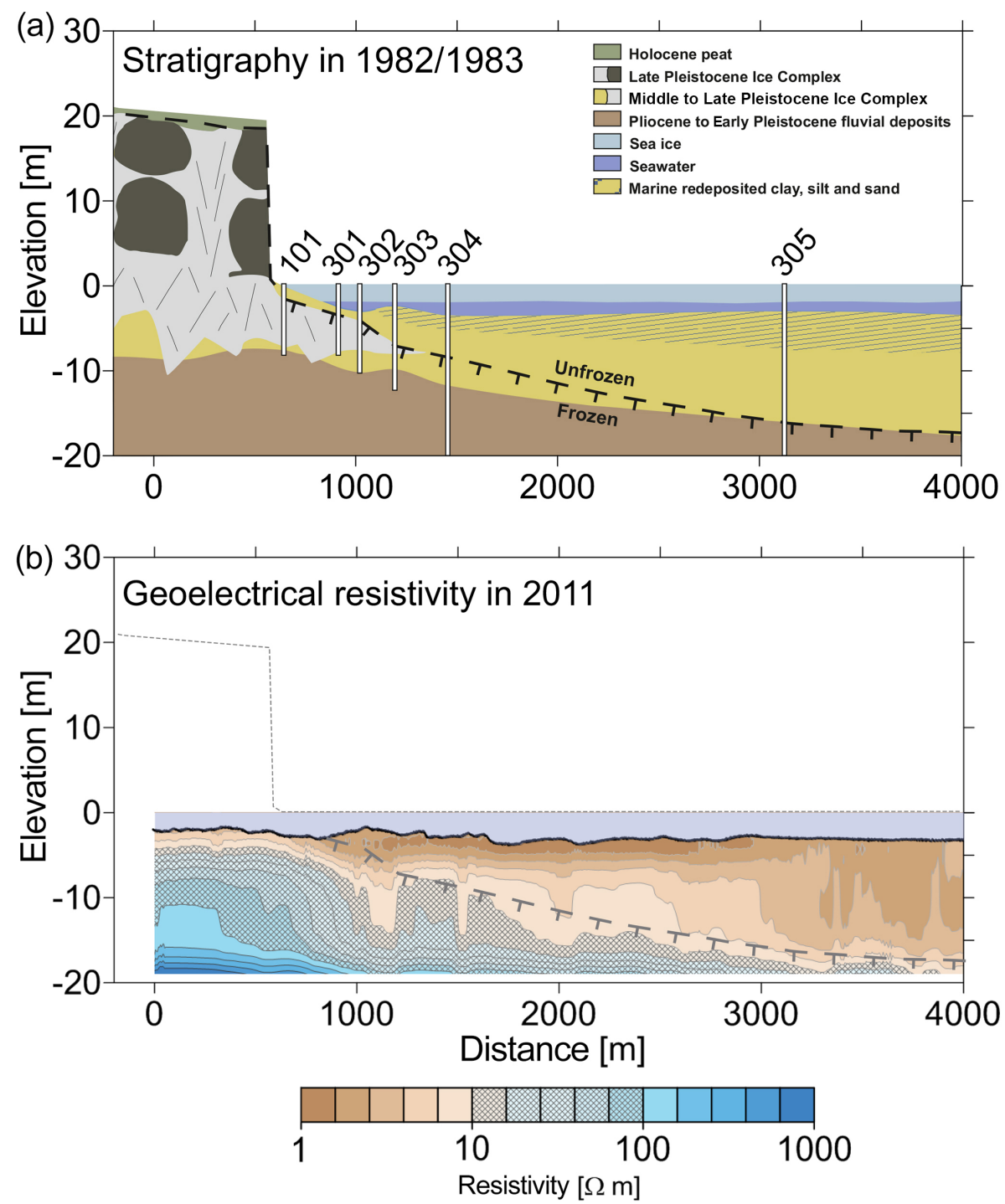

Figure 3. A comparison of the results of the drilling expedition in 1982 and 1983 with the inverted resistivity in 2011. The stratigraphy in the upper figure is based on the coastal exposures and the interpolation of borehole sediment stratigraphy, redrawn from Slagoda (2004). A range of resistivities (from 10 to $100 \Omega \mathrm{m}$ ), inverted from measured apparent resistivities, is indicated with crosshatching on the resistivity cross section in the lower figure. The position of the IBP interpolated from the boreholes is repeated on the lower figure (dashed grey line) for reference. The vertical exaggeration is 37 times.

treat resulted in the erosion of the coastal bluff and eroded the shoreface profile, increasing water depths by up to $3 \mathrm{~m}$. Changes in the bathymetric profile over 30 years from about $1.8 \mathrm{~km}$ out to $4 \mathrm{~km}$ were less than $0.4 \mathrm{~m}$ and probably within the uncertainty generated by interpolation of the historical bathymetry and by changes in water level. According to $\mathrm{Ku}-$ nitsky (1989), in 1983, water shallower than the thickness of the annual sea-ice cover extended out to around 150$200 \mathrm{~m}$ from the shore, corresponding to the extent of the BFI zone, which is separated from land-fast ice by cracks in sea ice. The intertidal zone exposed at low water levels and submerged at high water levels resulted in a foreshore zone width of up to $180 \mathrm{~m}$, where sea ice freezes to the bottom and isolated pockets of saline water may collect up to $41 \%$ o(Kunitsky, 1989). Along the drilling profile, the unfrozen sediment layer increased in thickness from this border towards the sea, while landwards and in sand bars a seasonally frozen layer developed (Fig. 3, upper profile). In 2011, the mean depth along the entire profile was $2.76 \mathrm{~m}$ (Fig. 3, lower profile).

\subsection{Water temperature and resistivity}

Benthic water electrical conductivity and temperature measured between September 2008 and September 2009 in $7.2 \mathrm{~m}$ water depth directly before the east coast of the northern end 
(a) Bottom water

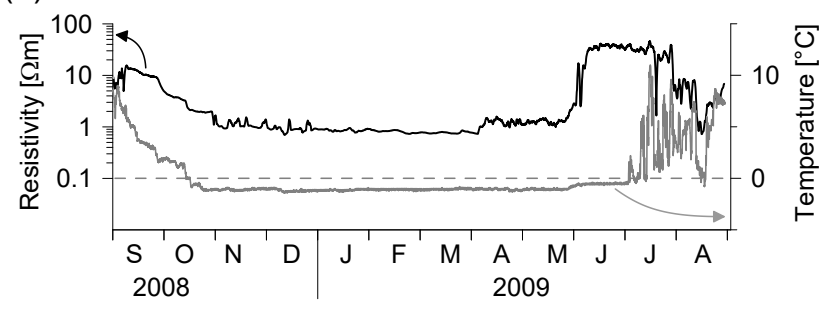

(b) Sediment porewater

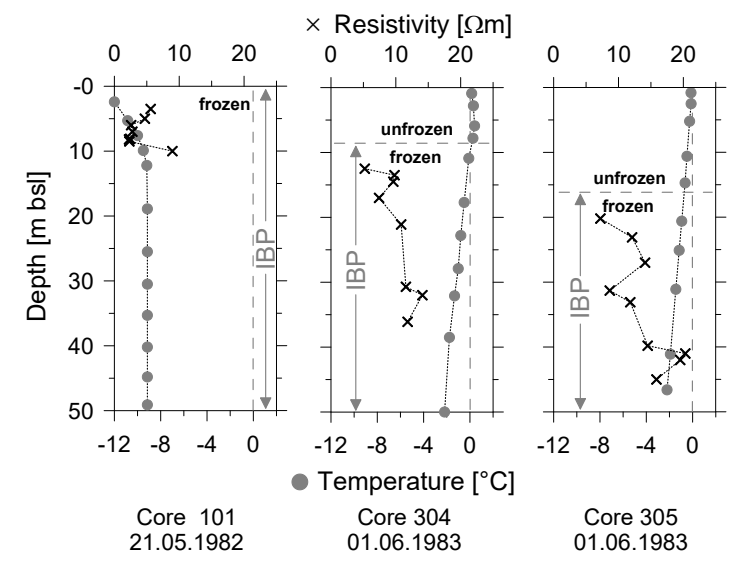

Figure 4. Water electrical resistivity and temperature are shown for (a) bottom water measured for the period 1 September 2008-31 August 2009 in $7.2 \mathrm{~m}$ water depth and (b) sediment porewater (based on Eq. 1) from cores recovered from boreholes 101, 304 and 305 on the dates indicated (Figs. 1 and 3; Table 1); temperature data are shown by grey lines, and circles and electrical resistivity data are shown by black lines and crosses.

of the island (Günther et al., 2013) varied strongly seasonally (Fig. 4a). Bottom water temperature dropped from over $8^{\circ} \mathrm{C}$ on 1 September to negative temperatures by 16 October 2008. During most of this period, bottom water resistivity also fell, from peak values of $35 \Omega \mathrm{m}$ to less than $2 \Omega \mathrm{m}$. At the end of the period of observation, from 28 July until the end of August in 2009, variations in temperature and resistivity fell within a similar range of values. After the late summer cooling period, from mid-October until the beginning of July, temperatures are below $-0.8^{\circ} \mathrm{C}$ and resistivity is below $3 \Omega \mathrm{m}$. In June, bottom water began to freshen at temperatures below $-1{ }^{\circ} \mathrm{C}$, eventually reaching summer values. In the early summer, following break-up of the sea ice, high resistivity $(>15 \Omega \mathrm{m})$ bottom water varied in temperature, reaching peak values of $12^{\circ} \mathrm{C}$.

Beneath the sea ice, from the end of October until after mid-May, bottom water electrical resistivity was below $1.7 \Omega \mathrm{m}$ (i.e. above a conductivity of $6 \mathrm{mS} \mathrm{cm}^{-1}$ ), whereas the influence of the Lena River discharge increased this value up to over $10 \Omega \mathrm{m}$ (corresponding to electrical conductivity below $1 \mathrm{mS} \mathrm{cm}^{-1}$ ) for the early summer (June). In
July, the freshwater at the sea bed warmed to over $10^{\circ} \mathrm{C}$. Winter resistivity varied less than $0.5 \Omega \mathrm{m}$, whereas openwater season resistivity (July to mid-October) varied between 0.1 and $30 \Omega \mathrm{m}$. The mean annual bottom water temperature was $2.1^{\circ} \mathrm{C}$, and the mean annual bottom water resistivity was $10 \Omega \mathrm{m}$ (corresponding to electrical conductivity of $0.09 \mathrm{mS} \mathrm{cm}^{-1}$ ).

The water in Buor Khaya Bay is generally stratified, with brackish water overlying colder saltier water. This position of this interface between the layers changes with time, in response to varying fluvial discharge rates and sea ice melting and freezing, and as a result of storm-generated mixing (Günther et al., 2013) but is usually lower than $7 \mathrm{~m}$ b.s.l. in summer. Geoelectric resistivity surveys took place in shallow water not subject to stratification. Seven surface water samples were collected during surveys on 20 and 24 August 2011. Their electrical conductivity was measured on the same day and ranged between 0.6 and $1.7 \Omega \mathrm{m}$. Based on these values, we used values of $0.65,0.98$ and $0.90 \Omega \mathrm{m}$ for the western, drilling and eastern profiles, respectively.

\subsection{Permafrost properties}

The permafrost of Muostakh Island belongs to Late Pleistocene Yedoma IC deposits that accumulated in the region between at least 46.8 and $19.5 \mathrm{ka} \mathrm{BP}$ based on radiocarbon ages (Schirrmeister et al., 2011a). It is overlain by a Holocene peat cover (Fig. 3). The IC is characterized by the occurrence of syngenetic ice wedges embedded in ice-rich silts and sands, peat horizons and a considerable overall amount of organic carbon (total organic carbon content of up to $5 \%$ by weight; Schirrmeister et al., 2011a). The oldest IC deposits lie up to $10 \mathrm{~m}$ below modern sea level at Muostakh Island and are underlain by silts, sands and gravels interpreted as fluvial deposits of Pliocene to Early Pleistocene age (Fig. 3; Slagoda, 2004). Syngenetic ice wedges of former polygon tundra are up to $5 \mathrm{~m}$ wide and up to decametres deep. Intrasedimentary ice occurs in horizontal to subhorizontal ice bands, ice lenses and ice cement. Ice wedges defined as macro ground ice by Günther et al. (2015) constitute up to $44 \pm 4.6 \mathrm{vol} \%$. Intrasedimentary ice adds another $43 \mathrm{vol} \%$ to the total ice content and sums up to $87 \mathrm{vol} \%$ (Günther et al., 2015). Along both sides of the island, this high ground ice content renders the coastline susceptible to thermo-erosion. Thermokarst mounds (baidzherakhs) are left over when ice wedges melt, leaving these former polygon centres of the Yedoma IC preserved on the coastal bluff. They exist on both coasts of Muostakh Island, which is underlain everywhere by Yedoma and shaped by Holocene thermokarst features, including an alas (former lake basin) that intersects the western coast midway up the island (Fig. 5).

Assuming the same geological subsurface of the island, i.e. mainly Yedoma IC, the different shape of the island's eastern and western shore is controlled by intensity of coastal erosion. As intensively studied by Günther et al. (2015) 


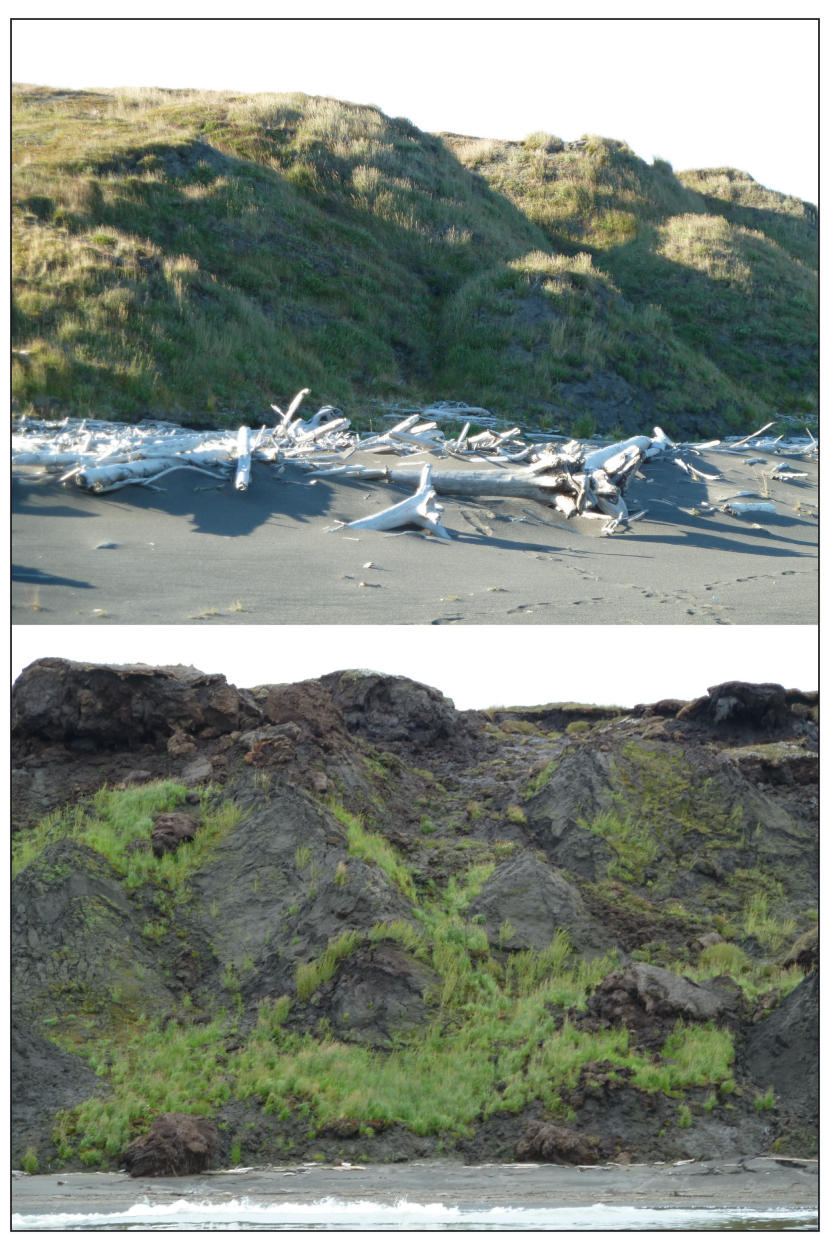

Figure 5. Photographs of the western (top panel) and eastern (bottom panel) coastal bluffs show similarities in the height $(\sim 22 \mathrm{~m})$ and morphology. The presence of thermokarst mounds (baidzherakhs) characterizes both coasts, but the comparatively stable western baidzherakhs are completely vegetated, whereas pioneer species are sparsely established on the eastern baidzherakhs. The top of the eastern coastal bluff has overhanging vegetative mats, below which melting polygon ice wedges are exposed. On the western coast, ice wedges have already melted to at least the depth of annual ground thaw.

the interplay of thermo-denudation and thermo-abrasion efficiently erodes the north-eastern coast while the western coast appears almost stable. Strong winds occur mainly during the winter season in an S to SW direction when the sea is icecovered (Günther et al., 2015) and have therefore no impact on coastal retreat. Due to its location close to the mainland coast, the maximum fetch from S to SW during the sea-icefree period is less than $50 \mathrm{~km}$, while the fetch from $\mathrm{N}$ to $\mathrm{NE}$ is nearly unlimited (Günther et al., 2015). The latter is of importance during the sea-ice break-up when wind events prevail in $\mathrm{N}$ to $\mathrm{NE}$ directions, and cause rising water level and constant heavy swells that promote marine abrasion (thermoabrasion).

\subsection{Borehole observations}

In the following analysis, we report borehole observations and geoelectric surveys with reference to depths or elevations relative to sea level. Since sea level changes over time, these results are not directly comparable. However, tidal variations around Tiksi are generally less than $10 \mathrm{~cm}$, although storm surges can lead to larger changes in sea level, up to $\pm 0.6 \mathrm{~m}$. The net change in mean annual sea level recorded three times per month at the Tiksi tide gauge between May 1983 and August 2011 was $0.12 \mathrm{~m}$ (data from Arctic and Antarctic Research Institute, St. Petersburg, accessed at www.whoi.edu/ science/po/arcticsealevel/laptev.html on 16 March 2015).

Borehole temperatures are available for the cores 101, 304 and 305 obtained after drilling in May 1982 and June 1983 (Fig. 4b; Kunitsky, 1989). The onshore core 101 shows the cold-temperature regime of terrestrial permafrost with almost stable ground temperatures of about $-9{ }^{\circ} \mathrm{C}$ at the time of measurement that decrease slightly due to the seasonal winter signal in the upper $10 \mathrm{~m}$ of the sediment (Fig. 4b). Both offshore cores 304 and 305 have temperatures that increase upwards from about $-2{ }^{\circ} \mathrm{C}$ at the borehole bottoms to $0^{\circ} \mathrm{C}$ at the sediment surface. Saline seawater lowers the porewater freezing temperature and decreases the resistivity in the upper part of the profile (Fig. 4b). The boundary between IBP and ice-free (unfrozen) permafrost lay at a depth of $8.3 \mathrm{~m}$ b.s.l. in core 304 and $16 \mathrm{~m}$ b.s.l. in core 305 . No boundary was encountered in core 101, which was frozen throughout. The IBP in the offshore boreholes was up to $7^{\circ} \mathrm{C}$ warmer than temperatures measured in borehole 101 at the shoreline.

\subsection{Profiles of electrical resistivity and bathymetry}

The results from three surveys conducted between 21 and 24 August 2011 are presented here. Two profiles of $1.5 \mathrm{~km}$ length perpendicular to the eastern and western coasts of the northern cape of Muostakh Island, as well as one longer profile $(4 \mathrm{~km})$ along the borehole profile drilled 28 years earlier (Figs. 1, 3 and 6; borehole 101 was drilled 29 years before surveying). Inverted bulk-sediment resistivities reached maximum values of $182 \Omega \mathrm{m}$ for the western profile, $180 \Omega \mathrm{m}$ for the drilling profile and $1300 \Omega \mathrm{m}$ for eastern profile. The depth to any of the isopleths of constant resistivity (e.g. 0, 40, $70 \Omega \mathrm{m}$ ) in 2011 was greater at each point along the drilling profile than the depth to frozen sediment observed in 1983. The range of values defined as containing the transition from thawed to frozen sediment ( 10 to $100 \Omega \mathrm{m}$ ) descended with distance from the coastline and extended beyond the maximum depth of the inversions from 220 to $500 \mathrm{~m}$ along the western profile, beyond $1050 \mathrm{~m}$ for the drilling profiles and beyond $1065 \mathrm{~m}$ for the eastern profile. The depths corresponding to this transition zone at the locations of cores 101, 304 and 305 were 5.9 to $17.4 \mathrm{~m}$ b.s.l., 9.8 to $>19 \mathrm{mb}$ b.s.l. and 18 to $>19 \mathrm{mb}$ b.s.l. determined using geoelectric soundings in 2011 (Fig. 3). The depth of the $10 \Omega \mathrm{m}$ contour along the 

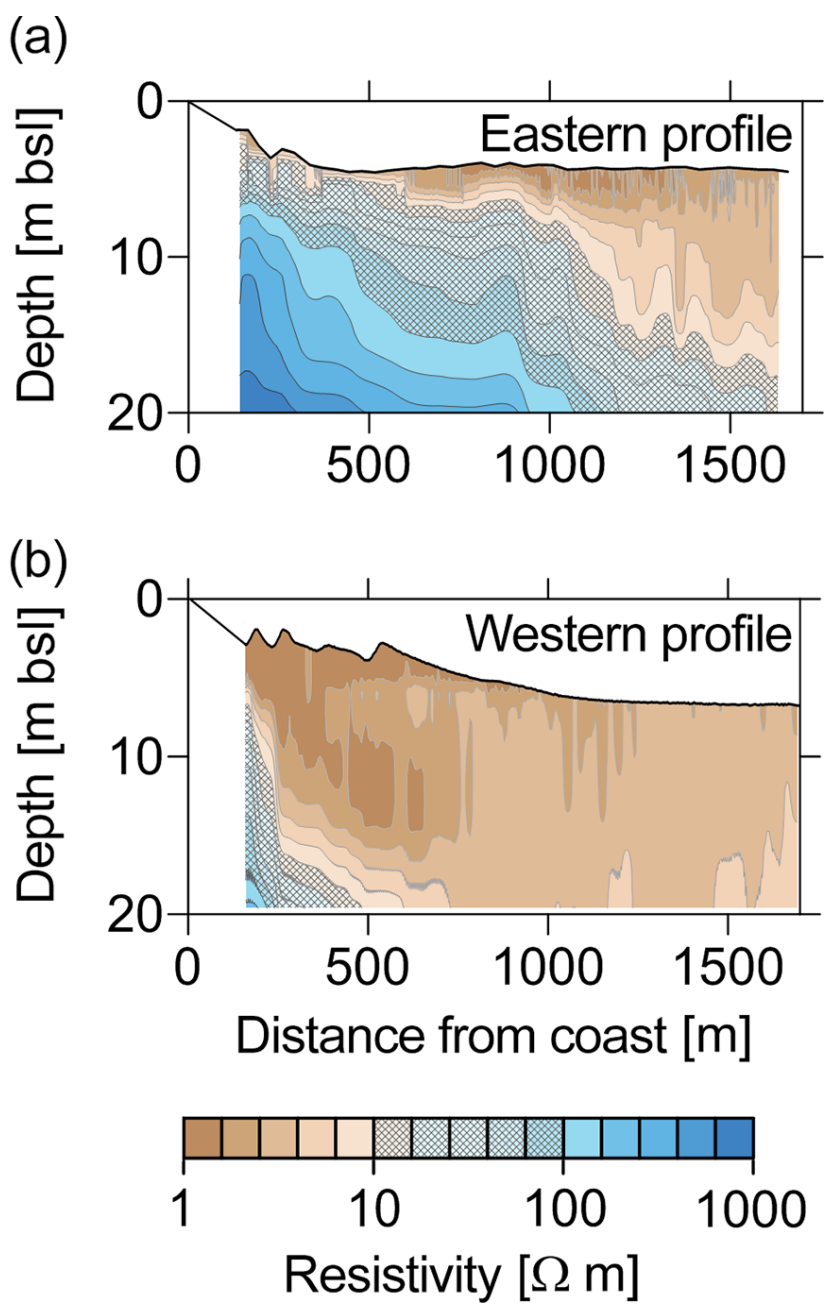

Figure 6. Inversions of the georesistivity of the eastern and western geoelectric profiles (positions shown in Fig. 1).

drilling profile (Fig. 3) shows more variability with distance from the coastline than in either of the other profiles. There are two pronounced dips of more than $4 \mathrm{~m}$, between borehole locations 302 and 303 and beyond borehole location 304 . Deeper contour lines no longer show this variability in depth. The $25 \Omega \mathrm{m}$ dips from 8.4 to $16.8,17.0,16.0,17.9$ and to more than $19 \mathrm{~m}$ depth at the borehole locations. Differences between the position of the IBP observed in sediment recovered from the boreholes and the $25 \Omega \mathrm{m}$ (normalized to period of inundation) increase from $0.3 \mathrm{~m} \mathrm{a}^{-1}$ at borehole 101 to $0.5 \mathrm{~m} \mathrm{a}^{-1}$ at boreholes 301 and 302 , and then decrease further offshore to $0.3 \mathrm{~m} \mathrm{a}^{-1}$ at boreholes 303 and 304 and to $0.1 \mathrm{~m} \mathrm{a}^{-1}$ at borehole 305 . If we arbitrarily choose the $25 \Omega \mathrm{m}$ as a proxy for IBP, then these rates correspond to submarine permafrost degradation rates. Choosing other values would give somewhat different rates, but the trend observed would be the same.

For geoelectric soundings within the 1951 coastline, we linearly interpolated coastline positions from remote sensing

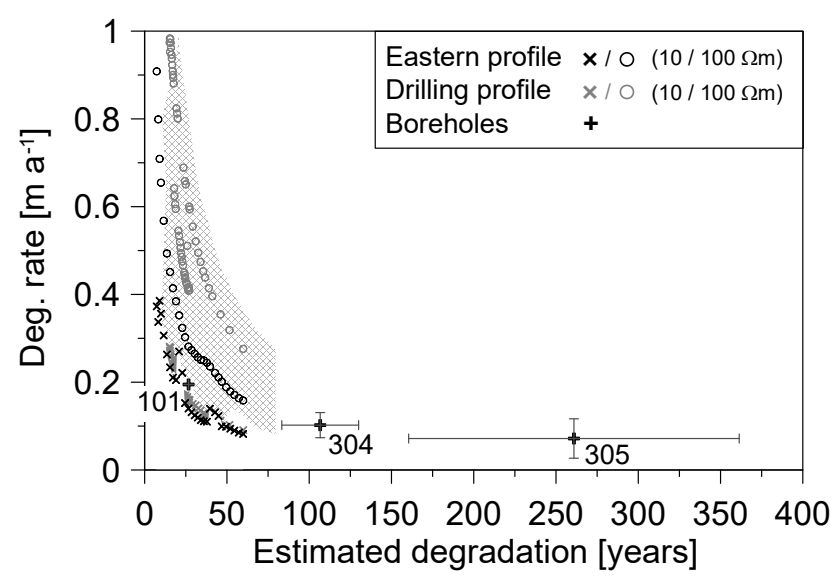

Figure 7. Permafrost degradation rate inferred from geoelectric soundings and their positions, for the eastern and borehole geoelectric profiles and for three boreholes indicated by number (diamonds). Only soundings/boreholes located within the region eroded since 1951 are used. Degradation rates shown for 10 and $100 \Omega \mathrm{m}$ are indicated with crosses and circles, respectively. The hatched area corresponds to the union of the hatched areas in Figs. $3 \mathrm{~b}$ and 6.

imagery to geoelectric sounding position to estimate the period of inundation at each sounding. Figure 7 shows inferred mean submarine permafrost degradation rates since inundation as a function of these periods for soundings along the drilling profile and eastern profile. Since no interim determinations of IBP table depth have been made since inundation, these degradation rates are mean rates for the period of inundation ending in 2011. Instantaneous rates of degradation at or nearer to the shoreline are probably higher. Results indicate that initial submarine permafrost degradation rates following inundation range between 0.4 and over $1.0 \mathrm{~m} \mathrm{a}^{-1}$ (using 10 and $100 \Omega \mathrm{m}$ isopleths), and that rates decrease over time, reaching mean values between 0.1 and $0.3 \mathrm{~m} \mathrm{a}^{-1} 60$ years after inundation. Assuming that the longterm erosion rate at the northern cape represents the mean rate since inundation, we can infer the duration of degradation for the borehole locations. In this case, the periods of inundation for boreholes 101, 304 and 305 were about 28,112 and 253 years, respectively. Rates thus inferred were $0.19,0.10$ and $0.07 \mathrm{~m} \mathrm{a}^{-1}$ (Fig. 7).

\section{Discussion}

\subsection{Permafrost degradation following erosion}

As coastal retreat progresses, the rate of IBP degradation slows (Hutter and Straughan, 1999). Are (2003) suggests using the distance from shoreline to approximate a timescale of inundation. Following this approach, the time of submergence at any point along the geoelectric profiles can be calculated based on the assumption that the longest available record of mean erosion rates (here observed over the past 60 
years) provides the best approximation for long-term mean annual erosion rates. The decrease in degradation rate for a prolonged period since inundation is visible in our geoelectric profiles as a steeper inclination of the IBP table closer to shore (Fig. 6). The length of inundation of points distal to the island are approximately 260 years on the eastern profile, and closer to 3500 years of erosion on the western profile (based on profile length of $1700 \mathrm{~m}$ and coastal retreat rates of 0.5 and $6.5 \mathrm{~m} \mathrm{a}^{-1}$, respectively). Using the positions of the geoelectrical soundings for which date of inundation can be inferred, there is a decrease in the rate of degradation over time (Fig. 7). Nixon (1986) models a mean degradation rate of $0.1 \mathrm{~m} \mathrm{a}^{-1}$ after 50 years of degradation for sediments with a freezing point of $-1.8^{\circ} \mathrm{C}$, matching the observations from the geoelectrical soundings shown in Fig. 3. Grigoriev (2008) shows a mean degradation rate of $0.05 \mathrm{~m} \mathrm{a}^{-1}$ for 12 profiles of IBP for the Laptev and East Siberian seas, with a range between 0.01 and $0.15 \mathrm{ma}^{-1}$. Over the long term, Nixon's 1986 model and these results show a decrease in degradation rate to levels less than $0.1 \mathrm{~m} \mathrm{a}^{-1}$, as the thermal and solute concentration gradients between the sea floor and the IBP table become less and less steep, decreasing fluxes of heat and salt, respectively.

Studies in Siberia and Alaska have shown that submarine permafrost degradation is most rapid following inundation, when the thickness of the unfrozen sediment layer overlying the IBP is small, and thermal and diffusion gradients are steepest (Are, 2003; Harrison, 1982). Slowing of degradation may also be the result of lower bulk thermal properties in the thawed sediment (Chuvilin et al., 2013). Figure 7 shows an asymptotic reduction in degradation rate as the length of inundation increases. The permafrost temperatures reported by Slagoda (2004) show warming of permafrost by almost $9^{\circ} \mathrm{C}$ within the first 100 years of inundation (Fig. 4b), up to the freezing temperature of the pore space solution. Based on coastal erosion rates for a 4-year period, Molochushkin (1978) estimates that warming of the permafrost off the eastern shore of Muostakh Island occurs at $0.4^{\circ} \mathrm{Ca}^{-1}$ over the first 10 years, but at an average rate of $0.25^{\circ} \mathrm{Ca}^{-1}$ for the first 30 years at a depth of $10 \mathrm{~m}$ below the sea floor.

\subsection{Comparing profiles}

Muostakh Island was chosen as our field site for studying submarine permafrost degradation because its coastal retreat rate varies widely within a small area, over which larger scale drivers, such as air temperature, sea-ice cover and storm events, can be assumed to be similar. Obvious differences between the eastern and western coasts include the orientation of the coastline, the potential maximum fetch before each coast and the relative influence of riverine water and alongshore currents. Mean coastal retreat rates on the western and eastern shores of the island have differed by a factor of 13 for the past decades. Along both shores, thermo-abrasion of the submarine shoreface results in offshore transport of sed- iment, creating a concave submarine profile shape from the waterline out to about $1 \mathrm{~km}$ from shore. In contrast, mean water depth along the drilling profile was more than $2.5 \mathrm{~m}$ based on bathymetry measured during geoelectric surveying, throughout the profile. Although we found no local seaice thickness data for Muostakh Island, this exceeds probable maximum sea-ice thickness. Ice thickness of $2.1 \mathrm{~m}$ was observed within $1 \mathrm{~km}$ of the coastline on the eastern shore of Buor Khaya Bay at the end of winter in 2012 (Günther et al., 2013). Sediment is thermo-abraded and deposited here in roughly equal measure. Differences in IBP depth along this profile are the result of differences in the duration and/or rate of IBP degradation. Differences between the western and eastern shores may be the result not only of differing IBP degradation rates and inundation periods but also of sediment budgets. Molochushkin (1978) attributes the thicker unfrozen sediment on the western side of Muostakh Island to the accumulation of marine sediment, whereas erosion of sediment determines the depth to the IBP off the eastern shoreline. The similarity of the shoreface profiles suggests that this explanation is not sufficient to explain differences in IBP table inclination, however. Molochushkin and Gavrivev (1982) also present interstitial salinity profiles for two cores from positions north-east of Muostakh Island (mean TDS $6.4 \mathrm{~g} / 100 \mathrm{~g}$ : $2.6 \Omega \mathrm{m}$ ) and west of Muostakh (mean TDS of $1.8 \mathrm{~g}$ per $100 \mathrm{~g}$; $<0.1 \Omega \mathrm{m}$ ), suggesting diffusion of seawater into the sediment rather than deposition under marine conditions.

The shape of the IBP table along the drilling profile is more complicated and may have depended on the shape of the northern cape over time. A distance $2.5 \mathrm{~km}$ from the 1983 coastline (core 305, Fig. 3) has probably been submerged for at least 250 years based on the mean erosion rate of $10 \mathrm{~m} \mathrm{a}^{-1}$ for the period of record. Along the drilling profile, $645 \mathrm{~m}$ of the geoelectric profile has been inundated since drilling took place in 1982 and 1983 (Fig. 3). In Fig. 3, the position of the IBP table is interpolated linearly between borehole sites. In the geoelectric profile (Fig. 3), its position relative to sea level is determined at soundings spaced between 2 and $5 \mathrm{~m}$ apart along the entire profile. The IBP table position based on geoelectric soundings therefore shows more detail than the borehole profile. It shows a pronounced dip of over $7 \mathrm{~m}$ (from 8.5 to $15.6 \mathrm{~m}$ b.s.l.) between the locations of boreholes 301 and 303, suggesting that the IBP there thawed more rapidly over the previous 28 years than locations closer to or further from shore. The slight rise in IBP beyond this dip corresponds to locally shallow parts of the 1983 bathymetry, where a sand bar resulted in water depth less than $1.5 \mathrm{~m}$ and where BFI probably formed each winter, allowing seasonal freezing of the sea floor (Kunitsky, 1989, borehole 303; also shown for Muostakh Island in Are, 2003). Although bathymetry can vary throughout the season and between years, the presence of BFI at least at the time of drilling may have led to cooling of the sediment and relative slowing of degradation locally (Osterkamp et al., 1989; Sellmann et al., 1992). 
BFI acts as a thermal couple between the seabed and the atmosphere in winter, due to the higher thermal conductivity of ice compared to seawater. This effect tends to delay permafrost degradation immediately after inundation, until bathymetry exceeds the maximum depth of winter ice thickness around $2 \mathrm{~m}$, and the sea bed is covered by bottom water throughout the year (Osterkamp, 2001). Therefore, our observations of shallower IBP in places of former sand bars suggest that submarine permafrost preservation through thermal coupling of BFI outpaces the degradation effect associated with elevated brine concentration and injection under BFI. The duration of degradation on the abscissa in Fig. 7 includes any periods of BFI formation, and can therefore include a period of initial retardation of degradation. Molochushkin (1978) reports mean annual seawater temperatures at Muostakh of $0.2-0.3^{\circ} \mathrm{C}$ and resistivities of $10 \Omega \mathrm{m}$. Although the frequency and depth of measurements are not reported, these values are cooler than the $2.1^{\circ} \mathrm{C}$ observed in this study but have the same mean salinity.

Differences in IBP depth between the eastern and western profiles may be the result of factors not observed in this study. For example, there may be systematic differences in benthic temperature and resistivity regimes on either side of Muostakh Island. We expect the sheltered western side to be less affected by the outflow of the Lena River on the eastern side, whereas we expect greater mixing and resuspension due to wave action on the eastern side, especially when winds are from the N to NNE, and/or fetch exceeds $100 \mathrm{~km}$. Such differences change boundary conditions for submarine permafrost and affect the degradation rate. Nonetheless, the differences in IBP depth and inclination observed on either side of the island are at least consistent with differences in relative erosion rates, even if permafrost degradation rates are assumed to be similar.

\subsection{Submarine permafrost degradation}

Our results indicate that permafrost degradation rates at Muostakh Island are consistent with those inferred for nearshore sites elsewhere on the Siberian shelf (Overduin et al., $2007,2015)$. Since we calculate a decrease in submarine permafrost degradation rate with increased duration of inundation, most of the Siberian shelf region, which has been inundated for longer periods, probably has lower rates than those observed here near the coastline. The degradation rates that we infer for Muostakh Island are probably typical for permafrost near the coast and the sea floor, where vertical thermal and solute concentration gradients within the sediment are steeper than for most of the shelf region. Following inundation, ice content decreases throughout submarine permafrost due to warming and the consequent thaw of pore ice. Nicolsky et al. (2012) shows this as an increase in water content based on assumed freezing characteristic curves. In this model, the rate of ice melt depends on a suite of conditions during and antecedent to inundation. However, at $74.5^{\circ} \mathrm{N}, 118^{\circ} \mathrm{E}$, for example, the depth of permafrost saturated to at least $50 \%$ by ice degrades from about 25 to $200 \mathrm{~m}$ b.s.f. (below the sea floor), a mean rate of just below $0.01 \mathrm{~m} \mathrm{a}^{-1}$ (Nicolsky et al., 2012). Romanovskii and Hubberten (2001) show even lower rates of degradation of icebonded permafrost (defined as liquid water contents of $<5 \%$ by weight). Such slow rates of degradation make it difficult to detect changes in IBP depth. Further difficulties result from high uncertainties associated with geophysical techniques. As we observed, short-term changes in sea level and sediment dynamics can also create problems for comparing measurements made on multi-year timescales.

The rate of coastal retreat influences the inclination of the IBP within the sediment. The IBP table inclinations along the three georesistivity profiles are consistent with a relationship between coastal retreat rate and the inclination of the IBP table. If erosion is rapid, the IBP table will tend to lie closer to the sediment surface (Fig. 8a; eastern profile). In cases where the coastal retreat rate is slow and permafrost degradation occurs, the inclination of the ice-bearing permafrost table will tend to be steeper (Fig. 8b; western profile). Thus, the duration of inundation and distance from the coastline are linked by the rate of coastline retreat, which is variable in time.

Observations of the inclination of the IBP table perpendicular to the coast in the Laptev and East Siberian seas show a high degree of spatial variability (Overduin et al., 2007), probably reflecting the temporally varying intensity of the processes described (Fig. 8c). Observing submarine permafrost depends on direct observation by drilling, sampling and temperature measurements (Fartyshev, 1993; Rachold et al., 2007) coupled with indirect observations using geophysical methods sensitive to property changes between frozen and unfrozen sediment. Since the coastal zone is highly dynamic, especially during spring melt and autumn freeze-up, the logistics of measurements and continuous monitoring are difficult, requiring innovative new instrumentation and platforms for use in shallow water.

\section{Conclusions}

Offshore borehole data from 1982 to 1983 near the coast of Muostakh Island show warming, salinization and increasing depth to ice-bonded submarine permafrost (IBP) with increasing distance from shore. Geoelectric surveys along the borehole profile 28 years later show that land has been inundated as a result of coastal erosion and suggest that the submarine permafrost created has degraded at mean rates of between 0.6 and $0.1 \mathrm{~m} \mathrm{a}^{-1}$ over decades to centuries. Based on comparison of two geoelectric profiles at an eroding and a stable stretch of coast we suggest that, other factors being equal, greater rates of coastal erosion generally lead to a shallower inclination of the IBP table close to shore. These results show that IBP degrades most rapidly immediately after it is inundated year round, and degradation rates slow 

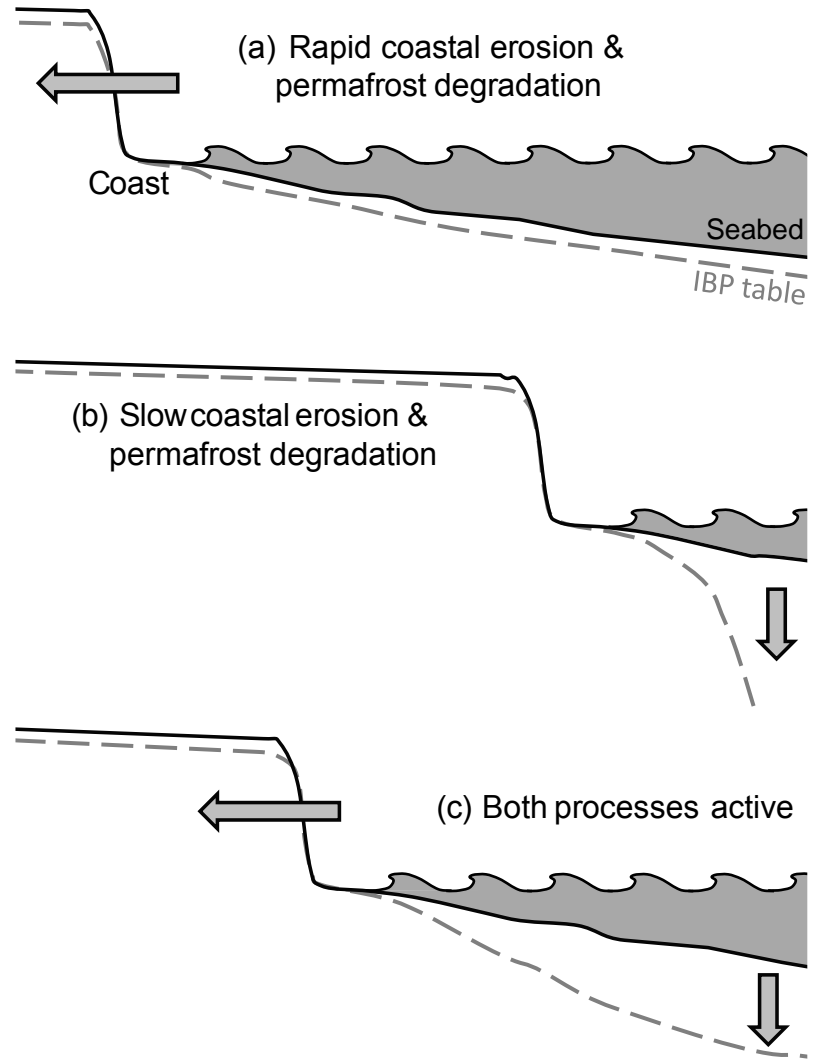

Figure 8. The relative rates of coastline retreat and permafrost degradation affect the shape of the ice-bonded permafrost (IBP) table beneath the shoreface profile sediment. In (a) rapid coastline retreat leads to an IBP table close to the sediment surface; in (b) a stable coastline leads to an IBP table that is more steeply inclined; in (c) most IBP table inclinations can be expected to reflect a complicated suite of factors, including temporally variable coastline retreat, permafrost degradation rates and near-shore sediment dynamics.

over time. On this basis, it is likely that degradation rates for most of the Siberian shelf permafrost are less than $0.1 \mathrm{~m} \mathrm{a}^{-1}$. We have shown that the coastal zone can produce estimates of degradation rates and that coastal dynamics and submarine permafrost degradation rates interact to determine the shape of the IBP table. This study suggests that much can be learned about how small-scale processes accelerate or slow the degradation of submarine permafrost through detailed study of local controls on thawing. Shallow bathymetry, for example, such as sand bars shallower than the maximum annual sea-ice thickness, may lead to temporary stabilization of permafrost following erosion. After characterizing shoreface bathymetry, geomorphology and sediment composition (particularly ice content), measurements of annual and seasonal variations in benthic and sediment temperature and salinity and measurements of sediment flux on the shoreface are needed.
Acknowledgements. This work was funded by a Helmholtz Association of Research Centres (HGF) Joint Russian-German Research Group (HGF JRG 100). SPOT imagery was provided by SPOT Planet Action - an Astrium GEO initiative (project: Coastal erosion in East Siberia). Invaluable logistical support was provided by the Russian Hydrogeological Service in Tiksi, the Lena Delta Reserve and Waldemar Schneider.

Edited by: T. Zhang

\section{References}

Are, F. E.: Thermal abrasion of sea coasts, Polar Geography and Geology, 12, 1-86, doi:10.1080/10889378809377343, from: Termoabraziya morskikh beregov, Nauka, Moscow, 1980, 158 pp., 1988.

Are, F. E.: Shoreface of the Arctic seas - a natural laboratory for subsea permafrost dynamics, in: Proceedings of the Eigth International Conference on Permafrost, Zürich, Switzerland, edited by: Philips, M., Springman, S. M., and Arenson, L. U., Swets \& Zeitlinger, Lisse, 27-32, 2003.

Barnes, D. F.: Geophysical methods for delineating permafrost, in: Proceedings of the International Conference on Permafrost, Lafayette, Indiana, 11-15 November, edited by Woods, K. B. and Alter, A. J., National Academy of Sciences, Washington, D.C., 349-355, 1963.

Barnhart, K. R., Overeem, I., and Anderson, R. S.: The effect of changing sea ice on the physical vulnerability of Arctic coasts, The Cryosphere, 8, 1777-1799, doi:10.5194/tc-8-17772014, 2014.

Bauch, H. A., Mueller-Lupp, T., Taldenkova, E., Spielhagen, R. F., Kassens, H., Grootes, P. M., Thiede, J., Heinemeier, J., and Petryashov, V. V.: Chronology of the Holocene transgression at the North Siberian margin, Global Planet. Change, 31, 125-139, doi:10.1016/S0921-8181(01)00116-3, 2001.

Boike, J., Kattenstroth, B., Abramova, K., Bornemann, N., Chetverova, A., Fedorova, I., Fröb, K., Grigoriev, M., Grüber, M., Kutzbach, L., Langer, M., Minke, M., Muster, S., Piel, K., Pfeiffer, E.-M., Stoof, G., Westermann, S., Wischnewski, K., Wille, C., and Hubberten, H.-W.: Baseline characteristics of climate, permafrost and land cover from a new permafrost observatory in the Lena River Delta, Siberia (1998-2011), Biogeosciences, 10, 2105-2128, doi:10.5194/bg-10-2105-2013, 2013.

Brown, J., Ferrians, O. J. J., Heginbottom, J. A., and Melnikov, E. S., eds.: Circum-Arctic map of permafrost and ground-ice conditions, Circum-Pacific Map Series CP-45, US Geological Survey in Cooperation with the Circum-Pacific Council for Energy and Mineral Resources, Washington, D. C., http://nsidc.org/data/ ggd318.html (last access: 5 May 2009), 2001.

Chuvilin, E. M., Bukhanov, B. A., Tumskoy, V. E., Shakhova, N. E., Dudarev, O. V., and Semiletov, I. P.: Thermal conductivity of bottom sediments inthe region of Buor-Khaya Bay (Shelf of the Laptev Sea), Earth Cryosphere, 17, 32-40, 2013.

Constable, S.: Ten years of marine CSEM for hydrocarbon exploration, Geophysics, 75, 75A67-75A81, 2010.

Corwin, R. F.: Marine permafrost detection using galvanic electrical resistivity methods, in: Offshore Technology Conference, 2 5 May, Houston, Texas, doi:10.4043/4480-MS, 1983. 
Dallimore, S. R. and Collett, T. S.: Intrapermafrost gas hydrates from a deep core hole in the Mackenzie Delta, Northwest Territories, Canada, Geology, 23, 527-530, doi:10.1130/0091-7613, 1995.

Dmitrenko, I. A., Kirillov, S. A., Tremblay, L. B., Kassens, H., Anisimov, O. A., Lavrov, S. A., Razumov, S. O., and Grigoriev, M. N.: Recent changes in shelf hydrography in the Siberian Arctic: Potential for subsea permafrost instability, J. Geophys. Res.Oceans, 116, C10027, doi:10.1029/2011JC007218, 2011.

Fartyshev, A. I.: Osobennosti priberezhno-shelfovoi kriolitozony morya Laptevykh (Characteristics of the near-shore Laptev Sea shelf), Russian Academy of Sciences, Siberian Branch, Nauka, Novosibirsk, 1993.

Fedorova, I., Chetverova, A., Bolshiyanov, D., Makarov, A., Boike, J., Heim, B., Morgenstern, A., Overduin, P. P., Wegner, C., Kashina, V., Eulenburg, A., Dobrotina, E., and Sidorina, I.: Lena Delta hydrology and geochemistry: long-term hydrological data and recent field observations, Biogeosciences, 12, 345-363, doi:10.5194/bg-12-345-2015, 2015.

Frolov, A. D.: Electric and elastic properties of frozen earth materials, ONTI PNC Russian Academy of Science Press, Pushchino, 1998.

Grigoriev, M. N.: Kriomorphogenez i litodinamika pribrezhnoshelfovoi zony morei Vostochnoi Sibiri (Cryomorhogenesis and lithodynamics of the East Siberian near-shore shelf zone), Habilitation thesis, Mel'nikov Permafrost Institute, Russian Academy of Sciences, Siberian Branch, Yakutsk, 2008.

Grigoriev, M. N., Kunitsky, V. V., Chzhan, R. V., and Shepelev, V. V.: On the variation in geocryological, landscape and hydrological conditions in the Arctic zone of East Siberia in connection with climate warming, Geogr. Nat. Resour., 30, 101-106, doi:10.1016/j.gnr.2009.06.002, 2009.

Günther, F., Overduin, P. P., Makarov, A. S., and Grigoriev, M. N. (Eds.): Russian-German cooperation SYSTEM LAPTEV SEA: the expeditions Laptev Sea - Mamontov Klyk 2011 \& Buor Khaya 2012, vol. 664 of Berichte zur Polar- und Meeresforschung (Reports on Polar and Marine Research), Alfred Wegener Institute, Bremerhaven, http://hdl.handle.net/10013/epic. 41834 (last access: 29 June 2016), 2013.

Günther, F., Overduin, P. P., Yakshina, I. A., Opel, T., Baranskaya, A. V., and Grigoriev, M. N.: Observing Muostakh disappear: permafrost thaw subsidence and erosion of a ground-ice-rich island in response to arctic summer warming and sea ice reduction, The Cryosphere, 9, 151-178, doi:10.5194/tc-9-151-2015, 2015.

Harrison, W. D.: Formulation of a model for pore water convection in thawing subsea permafrost, Mitteilungen der Versuchsanstalt für Wasserbau, Hydrologie und Glaziologie, 57, 3-24, 1982.

Hutter, K. and Straughan, B.: Models for convection in thawing porous media in support for the subsea permafrost equations, J. Geophys. Res.-Solid Ea., 104, 29249-29260, doi:10.1029/1999JB900288, 1999.

Kang, M. and Lee, J. S.: Evaluation of the freezing-thawing effect in sand-silt mixtures using elastic waves and electrical resistivity, Cold Reg. Sci. Technol., 113, 1-11, doi:10.1016/j.coldregions.2015.02.004, 2015.

King, M. S., Zimmerman, R. W., and Corwin, R. F.: Seismic and electrical properties of unconsolidated permafrost, Geophys. Prospect., 36, 349-364, 1988.
Kunitsky, V. V.: Kriolitologiya Nizovya Leny (Cryolithology of the Lower Lena), Melnikov Permafrost Institute, Russian Academy of Sciences, Siberian Branch, Yakutsk, 1989.

Lachenbruch, A. H.: Thermal effects of the ocean on permafrost, Bull. Geol. Soc. Am., 68, 1515-1530, doi:10.1130/0016-7606, 1957.

Lantuit, H., Atkinson, D., Overduin, P. P., Grigoriev, M., Rachold, V., Grosse, G., and Hubberten, H.-W.: Coastal erosion dynamics on the permafrost-dominated Bykovsky Peninsula, north Siberia, 1951-2006, Polar Res., 30, 7341, doi:10.3402/polar.v30i0.7341, 2011.

McGuire, A. D., Anderson, L. G., Christensen, T. R., Dallimore, S., Guo, L., Hayes, D. J., Heimann, M., Lorenson, T. D., Macdonald, R. W., and Roulet, N.: Sensitivity of the carbon cycle in the Arctic to climate change, Ecol. Monogr., 79, 523-555, doi:10.1890/08-2025.1, 2009.

Molochushkin, E. N.: The Effect of Thermal Abrasion on the Temperature of the Permafrost in the Coastal Zone of the Laptev Sea, in: Proceedings of the Second International Conference on Permafrost, Yakutsk, USSR, 13-28 July 1973, edited by: Sanger, F. J. and Hyde, P. J., vol. USSR Contributions, National Academy of Sciences, Washington, D.C., 90-93, 1978.

Molochushkin, E. N. and Gavrivev, R. I.: Structure, Phase Composition and Heat Regime of the Bottom of the Coastal Laptev Sea, in: The Arctic ocean and Its Coast in the Cenzoic Era (Severnyi Ledovityi Okean i Ego Poberezh'e v Kainozoe), edited by: Tolmachev, A. I., Amerind Publishing Co. Pvt. Ltd., New Delhi, p. 564, 1982.

Nicolsky, D. J., Romanovsky, V. E., Romanovskii, N. N., Kholodov, A. L., Shakhova, N. E., and Semiletov, I. P.: Modeling sub-sea permafrost in the East Siberian Arctic Shelf: The Laptev Sea region, J. Geophys. Res.-Earth Surf., 117, F03028, doi:10.1029/2012JF002358, 2012.

Nixon, J. F.: Thermal simulation of subsea saline permafrost, Can. J. Earth Sci., 23, 2039-2046, doi:10.1139/e86-188, 1986.

Osterkamp, T. E.: Sub-sea permafrost, in: Encyclopedia of ocean sciences, vol. 5, edited by: Steele, J. H., Thorpe, S. A., and Turekian, K. K., Academic Press, New York, London, 2902 2912, 2001.

Osterkamp, T. E., Baker, G. C., Harrison, W. D., and Matava, T.: Characteristics of the Active Layer and Shallow Subsea Permafrost, J. Geophys. Res.-Oceans, 94, 16227-16236, doi:10.1029/JC094iC11p16227, 1989.

Overduin, P. P., Hubberten, H.-W., Rachold, V., Romanovskii, N. N., Grigoriev, M. N., and Kasymskaya, M.: The evolution and degradation of coastal and offshore permafrost in the Laptev and East Siberian Seas during the last climatic cycle, in: Coastline Changes: Interrelation of Climate and Geological Processes, vol. 426, edited by: Harff, J., Hay, W., and Tetzlaff, D., The Geological Society of America, Boulder, CO, 97-111, doi:10.1130/2007.2426(07), 2007.

Overduin, P. P., Westermann, S., Yoshikawa, K., Haberlau, T., Romanovsky, V., and Wetterich, S.: Geoelectric observations of the degradation of nearshore submarine permafrost at Barrow (Alaskan Beaufort Sea), J. Geophys. Res.-Earth Surf., 117, F02004, doi:10.1029/2011JF002088, 2012.

Overduin, P. P., Liebner, S., Knoblauch, C., Günther, F., Wetterich, S., Schirrmeister, L., Hubberten, H.-W., and Grigoriev, M. N.: Methane Oxidation Following Submarine Per- 
mafrost Degradation: Measurements from a Central Laptev Sea Shelf Borehole, J. Geophys. Res.-Biogeo., 120, 965-978, doi:10.1002/2014JG002862, 2015.

Ping, C.-L., Michaelson, G. J., Guo, L., Jorgenson, M. T., Kanevskiy, M., Shur, Y., Dou, F., and Liang, J.: Soil carbon and material fluxes across the eroding Alaska Beaufort Sea coastline, J. Geophys. Res.-Biogeo., 116, G02004, doi:10.1029/2010JG001588, 2011.

Rachold, V., Bolshiyanov, D. Y., Grigoriev, M. N., Hubberten, H.-W., Junker, R., Kunitsky, V. V., Merker, F., Overduin, P., and Schneider, W.: Nearshore arctic subsea permafrost in transition, Eos T. Am. Geophys. Un., 88, 149-150, doi:10.1029/2007EO130001, 2007.

Romanovskii, N. N. and Hubberten, H.-W.: Results of Permafrost Modelling of the Lowlands and Shelf of the Laptev Sea Region, Russia, Permafrost Periglac., 12, 191-202, doi:10.1002/ppp.387, 2001.

Schirrmeister, L., Grosse, G., Wetterich, S., Overduin, P. P., Strauss, J., Schuur, E. A. G., and Hubberten, H.-W.: Fossil organic matter characteristics in permafrost deposits of the northeast Siberian Arctic, J. Geophys. Res.-Biogeo., 116, G00M02, doi:10.1029/2011JG001647, 2011a.

Schirrmeister, L., Kunitsky, V., Grosse, G., Wetterich, S., Meyer, H., Schwamborn, G., Babiy, O., Derevyagin, A., and Siegert, C.: Sedimentary characteristics and origin of the Late Pleistocene Ice Complex on north-east Siberian Arctic coastal lowlands and islands - A review, Quatern. Int., 241, 3-25, doi:10.1016/j.quaint.2010.04.004, 2011b.

Scott, W. J., Sellmann, P. V., and Hunter, J. A.: Geophysics in the Study of Permafrost, in: Geotechnical and Environmental Geophysics, edited by: Ward, S., Soc. of Expl. Geoph., Tulsa, 355384, 1990.
Sellmann, P. V., Delanney, A. J., and Arcone, S. A.: Coastal submarine permafrost and bedrock observations using dc resistivity, vol. 89-13 of US Army Cold Regions Research and Engineering Laboratory (CRREL) Report, National Technical Information Service, Hanover, New Hampshire, 1989.

Sellmann, P. V., Delaney, A. J., Chamberlain, E. J., and Dunton, K. H.: Seafloor temperature and conductivity data from Stefansson Sound, Alaska, Cold Reg. Sci. Technol., 20, 271-288, doi:10.1016/0165-232X(92)90034-R, 1992.

Shakhova, N. and Semiletov, I.: Methane release and coastal environment in the East Siberian Arctic shelf, J. Mar. Syst., 66, 227-243, doi:10.1016/j.jmarsys.2006.06.006, 2007.

Slagoda, E. A.: Genesis i mikrostroenie kriolitogennykh otlozhenii Bykovskogo polyostrova i ostrova Muoastakh (Genesis and microstructure of cryolithogenic deposits at the Bykovsky Peninsula and the Muostakh Island), PhD thesis, Mel'nikov Permafrost Institute, Russian Academy of Sciences, Siberian Branch, Yakutsk, 1993.

Slagoda, E. A.: Kriolitogennye otlozheniya primorskoi ravniny morya Laptevykh: litologiya i mikromorfologiya (poluostrov Bykovskiy i ostrov Muostakh) - Cryolitogenic sediments of the Laptev Sea coastal lowland: lithology and micromorphology (Bykovsky Peninsula and Muostakh Island), Ekspress, Tyumen, 2004.

Solomon, S. M., Taylor, A. E., and Stevens, C. W.: Nearshore Ground Temperatures, Seasonal Ice Bonding, and Permafrost Formation Within the Bottom-Fast Ice Zone, Mackenzie Delta, NWT, in: Proceedings of the Ninth International Conference on Permafrost, Fairbanks, Alaska, 29 June-3 July, 1675-1680, 2008. 